\title{
Declines in both redundant and trace species characterize the latitudinal diversity gradient in tintinnid ciliates
}

\author{
John R Dolan ${ }^{1}$, Eun Jin Yang ${ }^{2}$, Sung-Ho Kang ${ }^{2}$ and Tae Siek Rhee ${ }^{2}$ \\ ${ }^{1}$ Laboratoire d'Océanography de Villefranche-sur-Mer, CNRS, Université Pierre et Marie Curie (Paris 6) \\ Villefranche-sur-Mer, France and ${ }^{2}$ Department of Polar Ocean Environment, Korea Polar Research Institute, \\ Yeonsu-gu, Incheon, South Korea
}

\begin{abstract}
The latitudinal diversity gradient is a well-known biogeographic pattern. However, rarely considered is how a cline in species richness may be reflected in the characteristics of species assemblages. Fewer species may equal fewer distinct ecological types, or declines in redundancy (species functionally similar to one another) or fewer trace species, those occurring in very low concentrations. We focused on tintinnid ciliates of the microzooplankton in which the ciliate cell is housed inside a species-specific lorica or shell. The size of lorica oral aperture, the lorica oral diameter (LOD), is correlated with a preferred prey size and maximum growth rate. Consequently, species of a distinct LOD are distinct in key ecologic characteristics, whereas those of a similar LOD are functionally similar or redundant species. We sampled from East Sea/Sea of Japan to the High Arctic Sea. We determined abundance distributions of biological species and also ecological types by grouping species in LOD size-classes, sets of ecologically similar species. In lower latitudes there are more trace species, more size-classes and the dominant species are accompanied by many apparently ecologically similar species, presumably able to replace the dominant species, at least with regard to the size of prey exploited. Such redundancy appears to decline markedly with latitude in assemblages of tintinnid ciliates. Furthermore, the relatively small species pools of the northern high latitude assemblages suggest a low capacity to adapt to changing conditions.
\end{abstract}

The ISME Journal (2016) 10, 2174-2183; doi:10.1038/ismej.2016.19; published online 18 March 2016

\section{Introduction}

A very wide variety of taxa, both multicellular and microbial, show a latitudinal diversity gradient (Gaston and Spicer, 2003). Typically, species richness peaks in the tropics, often at $\sim 20^{\circ}$, dips slightly at the equator and decreases markedly with latitude both north and south. Tintinnid ciliates of the marine microzooplankton literally provide a textbook example of the pattern (Gaston and Spicer, 2003). Slight variations of the pattern characterize other protist taxa of the marine plankton such as foraminifera (Rutherford et al., 1999) and Ceratium species of the phytoplankton (Dolan, 2011). The latitudinal diversity gradient is the oldest known biogeographic pattern and the mechanisms generating it have long been debated with dozens of theories proposed, none of which has found wide acceptance

Correspondence: JR Dolan, Laboratoire d'Oceanography de Villefranche-sur-Mer, CNRS, Université Pierre et Marie Curie (Paris 6) UMR 7093, Station Zoologique, B.P. 28, 06230 Villefranchesur-Mer, France.

E-mail: dolan@obs-vlfr.fr

Received 29 April 2015; Received 26 November 2015; accepted 12 January 2016; published online 18 March 2016
(Willig et al., 2003). A universal explanation of the latitudinal diversity gradient has been termed 'The Holy Grail of Ecology' (Adams, 2009). Thus, although there is little agreement as to why the gradient exists, most do acknowledge that species richness often declines with latitude (Adams, 2009). The structure of species assemblages quite likely often differs with species richness but exactly how is difficult to predict. Declines in species richness can be reflected in various ways with different consequences concerning the ecological characteristics of a species assemblage.

Fewer species can represent a reduction in the overall variety or range of species within an assemblage. Less variety among species can translate into a lower capacity to respond to changes in resource composition or predation pressure. For example, a smaller range of consumer species could have a lower capacity to exploit changes in the size or qualities of available prey items. Alternatively, lower species richness may represent only fewer forms present in very low concentrations, outside their usual habitat, members of the 'accidental biosphere' (Weisse, 2014). These species likely have low actual or potential ecological impact. Besides a 
decline in variety, lower species richness may translate into fewer presumptive redundant species (that is, species of similar ecological characteristics) able to replace dominant species subject to a high specific mortality. Theoretically, the presence of redundant species should increase the resilence of an assemblage, meaning its capacity to resist perturbation and survive changes in conditions (Naeem, 1998).

Recent studies have re-emphasized the tremendous diversity of protists in the marine plankton (de Vargas et al., 2015). The phylogenetic diversity and extreme ecological complexity of protistan assemblages makes assessing how assemblages are structured a daunting task (for example, LimaMendez et al., 2015). Among planktonic protists, tintinnids are an example of a phylogenetically and ecologically coherent group and so represent a taxon in which study of the structure of assemblages are considerably simplified. Tintinnid ciliates also represent an ideal group to examine with regard to the question of how the structure of species assemblages varies with latitude. This is because not only do they show a typical latitudinal diversity gradient but also the population structure of temperate, sub-tropical and tropical populations are well known and species of similar ecology share similar morphologies allowing identification of ecologically redundant species.

Tintinnid ciliates are characterized by the possession of a shell or lorica whose architecture and dimensions form the basis of classic taxonomic schemes (Figure 1). About 1200 species are in the literature (Agatha and Strüder-Kypke, 2012); virtually all are restricted to the marine plankton. The diameter of the mouth-end of the lorica, lorica oral diameter (LOD), is a conservative taxonomic character (Laval-Peuto and Brownlee, 1986). It does not change with development; newly divided cells form a new lorica with the same oral diameter as the fully developed organism (Agatha et al., 2013).

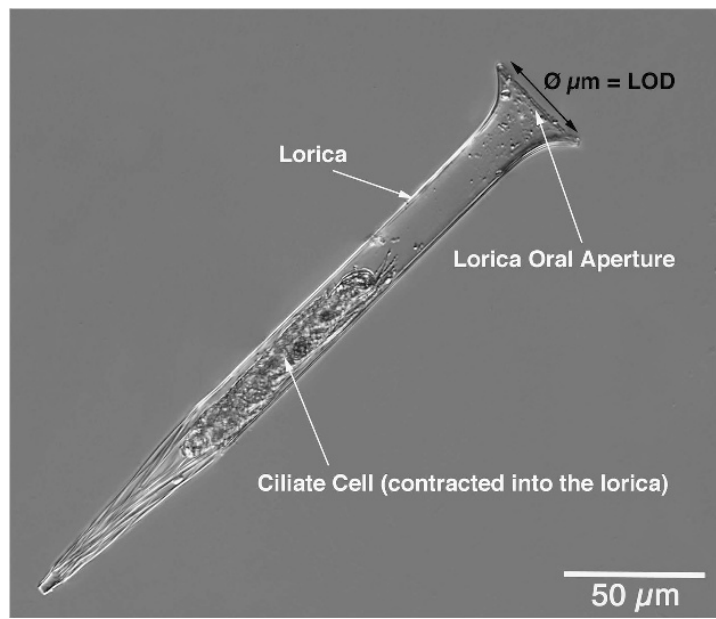

Figure 1 Salpingella acuminata. Image of a specimen from station 10 in the Bering Sea showing the basic features of a tintinnid ciliate.
Critically, LOD, analogous to gape-size, is related to both the size of the food items ingested and maximum growth rate. The largest prey item ingested is $\sim 0.5$ the LOD in longest dimension and a given species feeds most efficiently on prey $\sim 0.25$ of its LOD in size. LOD is negatively related to maximum growth rate. This is because LOD is positively related to the volume of the cell occupying the lorica (Dolan, 2010) and tintinnids follow the common inverse relationship between cell size and maximum specific growth rate (Montagnes, 2013). Tintinnid species with a similar LOD, or mouth size, are usually similar in terms of both preferred prey size and maximum growth rate; here these similarities are taken as indicating ecological redundancy.

The structure of tintinnid populations, in terms of both species abundance distributions and distributions of species grouped in size-classes, has been characterized for the species-rich assemblages of tropical, sub-tropical and temperate systems (Dolan et al., 2007, 2013). Typically in these systems, dozens of species can be found in material from 10 to $20 \mathrm{l}$ (Dolan and Stoeck, 2011). In general, species abundance distributions are log-series or lognormal distributions, whereas grouping forms by sizeclasses rather than species yields a geometric distribution (Dolan et al., 2007, 2013). Assemblages are overall structured by 'mouth size'. Typically there are 4-10 abundant species and these are of mouth sizes distinct from one another. The other species, of markedly less abundance, can be divided into two groups. The first is composed of those with mouth sizes similar to one of the dominant species; these are ecologically redundant forms. The second group is formed of species in LOD size-classes distinct from those of the dominants and these species appear to be occasional, ephemeral, or rare species (Dolan et al., 2009) and are generally present in very low concentrations (Dolan et al., 2013). However, it is important to note that the categories of 'redundant' and trace or 'rare' are not exclusive. If a species found in trace concentrations is in a size-class with other species, then it is both redundant and rare while if alone in a size-class then it is not redundant but rare with ecological characteristics distinct from all the other species.

Tropical, sub-tropical and temperate assemblages are characterised by high species richness reflecting both considerable species redundancy as well as the presence of species with morphologies distinct from abundant forms but found in low concentrations. In this study we address the question of how sub-arctic and arctic communities with lower species richness are structured compared with well-studied temperate communities.

We characterized communities along a latitudinal gradient of decreasing species richness. We examined large-scale or metapopulation characteristics in terms of species and in terms of 'ecotypes', defined here as species of similar feeding ecology and maximum growth rate based on LOD or mouth size. In 2012 we sampled populations of the East Sea/Sea of Japan, 
the North Pacific Ocean, the Bering Sea and the Chukchi Sea and the High Arctic along a transect of over $43^{\circ}$ of latitude and $5000 \mathrm{~km}$ (Figure 2). Notably the year 2012 was a year of record low sea ice extent permitting open water sampling of plankton in the High Arctic, to our knowledge for the first time. For each system two to six stations were sampled providing at least 2000 ciliate cells representing each assemblage. The parameters estimated for each of the five populations were species richness, number of trace species (found as a single cell), number of mouth size-classes, proportion of size-classes with multiple occupants (containing more than one species) and the number of apparently redundant species. For each assemblage the observed pattern of species abundance distribution was compared with modeled abundance curves constructed using parameters of the particular assemblage for three common models of community organization: geometric, log-normal and log-series. Substituting size-class of oral diameter for 'species', we also determined size-class abundance distributions.

\section{Materials and methods}

Sampling and sample analysis

Data and samples were collected from onboard the Korean Research Icebreaker Araon from July to September in 2012. Data presented here are from 22 stations distributed between the Japan Sea and $82{ }^{\circ} \mathrm{N}$ as shown in Figure 1. Exact locations and the Korean Polar Research Station Designations are given in the supplementary data file. A Niskin bottle rosette equipped with CTD probes was used to obtain temperature profile data and discrete depth samples for chlorophyll determinations. Plankton net tows were performed to assess microplankton community composition.

For chlorophyll a determinations, water samples of 0.3-1 l were obtained from 7 to 9 discrete depths between the surface and $100 \mathrm{~m}$ depth. Water samples were filtered through a $0.7 \mu \mathrm{m}$ Whatman glass fiber filter $(\mathrm{GF} / \mathrm{F})$ and chlorophyll concentrations determined onboard using a Turner Designs Trilogy model fluorometer calibrated using commercial chlorophyll a standards.

Net tows were made with a $20 \mu \mathrm{m}$ mesh plankton net of $0.45 \mathrm{~m}$ diameter towed from $100 \mathrm{~m}$ depth to the surface, except at some shallow stations sampled from 50 or $30 \mathrm{~m}$ depth. A portion of the net tow material was fixed with Lugol's fixative solution ( $2 \%$ final concentration) for direct microscopic examination. In the laboratory, multiple 1-2 $\mathrm{ml}$ aliquots of net tow material were diluted and examined in $3 \mathrm{ml}$ settling chambers using an inverted microscope equipped with differential interference contrast optics. The entire surface of the settling chamber was examined at $\times 200$ total magnification. Tintinnid identifications were made based on lorica morphology and following

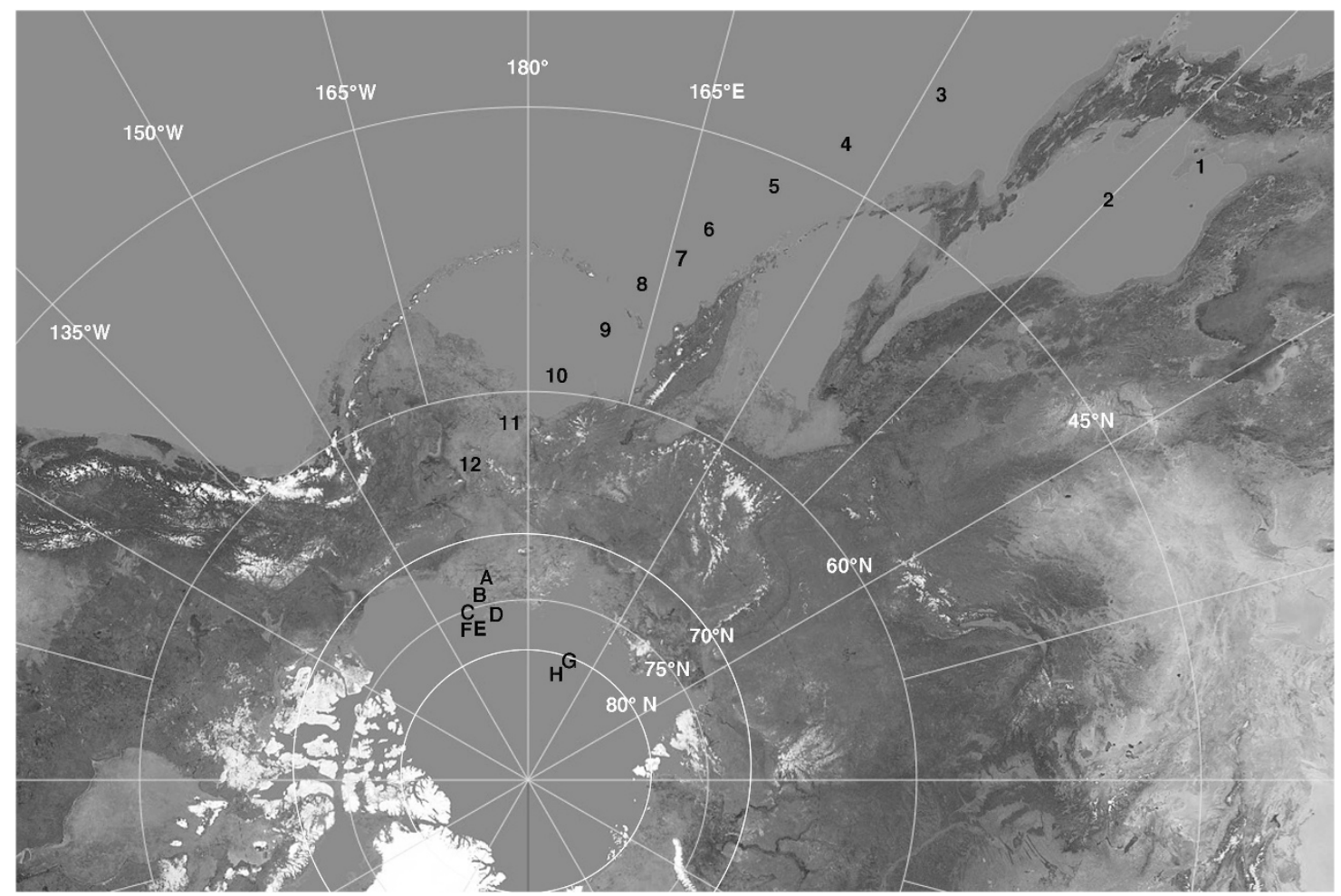

Figure 2 Locations sampled between late July and early September in 2012 ranging from the East Sea/Sea of Japan (1 and 2), across the North Pacific (3-8), the Bering Sea (9-12), the Chukchi Sea (A-F) and the High Arctic (G and H). The summer of 2012 was the year of record low sea ice extent allowing sampling in the High Arctic Sea. See supplementary data file for exact station locations and summary station data. 
Kofoid and Campbell (1929, 1939) and Hada (1937). We adopted a conservative approach, distinguishing all forms corresponding to species currently recognized as valid. Species names, occurrences and LOD diameters assigned are given in the supplementary data file. As previously described and justified (Dolan et al., 2006, 2007, 2009, 2013), species of similar ecology in terms of preferred prey size and maximum growth rate were grouped based on (LOD). Each species was assigned the average dimensions reported in Kofoid and Campbell $(1929,1939)$ and Hada (1937). Size-class diameters were binned over $4 \mu \mathrm{m}$ intervals beginning with the overall smallest diameter $(11 \mu \mathrm{m})$ and continuing to the largest diameter encountered in a given sample.

Total sample volumes examined varied, depending on the concentrations of organisms, and the dilutions employed varied according to concentrations of phytoplankton. However, multiple aliquots were examined until material from at least 100 liters filtered by the net was analyzed for each station. Nominal concentrations of organisms (given in the supplementary file) were calculated based on the volume filtered by the net (calculated from net surface area and depth of the strata sampled) and the volume of net tow material examined. It should be noted that the concentrations reported here are the average values per liter for the portion of the water column sampled, for most stations the top $100 \mathrm{~m}$.

\section{Data analysis}

Tintinnid assemblages were characterized by pooling data by system: East Sea/Sea of Japan stations 1-2; North Pacific stations 3-8; Bering Sea stations 9-12, Chukchi Sea stations A-F and the High Arctic Sea stations G-H. The parameters estimated for each of the five populations were species richness, number of trace species (found as a single cell), number of mouth size-classes, proportion of size-classes containing more than one species (multiple occupants) and the number of apparently redundant species. We used simple linear correlation analysis to examine relationships across all stations between species richness and latitude, water temperature, organismal concentrations and chlorophyll a concentrations.

For each assemblage we examined the patterns of both species abundance distribution and the abundance distributions of LOD size-classes. We first made log-rank abundance curves by calculating relative abundance for each species and ranking species from highest to lowest and plotting ln (relative abundance) vs rank. Then, we constructed hypothetical log-rank abundance curves that could fit the data by using parameters of the particular assemblage. We produced curves for three common models of community organization: geometric series, log-series and log-normal, as in several previous studies (Raybaud et al., 2009; Claessens et al., 2010; Doherty et al., 2010; Dolan et al., 2007, 2009, 2013; Dolan and Stoeck, 2011).
The observed rank abundance distributions were compared with the hypothetical models using a Bayesian approach: an Akaike goodness of fit calculation (19). Using this approach, an Akaike Information Criterion was determined as the natural logarithm of the mean (sum divided by $S$ ) of squared deviations between observed and predicted in (relative abundance) for all ranked $S$ species plus an additional term to correct for the number of estimated parameters, $k$ ( 1 for geometric series and 2 each for log-series and log-normal distributions): $(S+k) /(S-k-2)$. The lower the calculated Akaike Information Criterion value, the better the fit. A difference of 1 in Akaike Information Criterion corresponds roughly to a 1.5 evidence ratio; we considered that a minimum difference of 1.0 between Akaike Information Criterion values was required to represent a significantly different fit following Burnham and Anderson (2002).

\section{Results and discussion}

The expected latitudinal decline of species richness was evident. In the East Sea/Sea of Japan species richness was much higher than in the higher latitude systems. The East Sea/Sea of Japan also had higher cell and chlorophyll a concentrations. However, plotting individual station data showed the decline in species richness across the five systems to be more closely relatable to sea surface temperature rather than latitude, and independent of the abundance of tintinnid cells or chlorophyll concentrations (Figure 3).

The dominant species in each assemblage (shown in Supplementary Figure 1) were small-mouthed species, Proplectella expolita, Condonellopsis frigida, Acanthostomella norvegica except in the North Pacific where the relatively large-mouthed Ptychocylis obtusa dominated. In each assemblage, the dominant species accounted for $45-86 \%$ of the cells encountered (Table 2). Overall, of the 31 species found most (25) were not widely distributed but rather found in only in one or two of the systems sampled. In contrast, four species were found in all five populations sampled. These widespread forms were four of the six species found in the High Arctic Sea. Thus, the few species found in the High Arctic are mostly the widely distributed forms (for details distributions of each species distributions see the supplementary data file 'species data').

The populations in the East Sea/Sea of Japan differed considerably from all of the high latitude assemblages (Table 1). Overall species richness was similar to that reported for stations from the California Current system in the Eastern Pacific at about the same latitude (Dolan et al., 2013). The 25 species of the East Sea/Sea of Japan assemblage were distributed in 11 size-classes, most of which were occupied by more than one species. Thus, a large portion of the species pool was composed of 


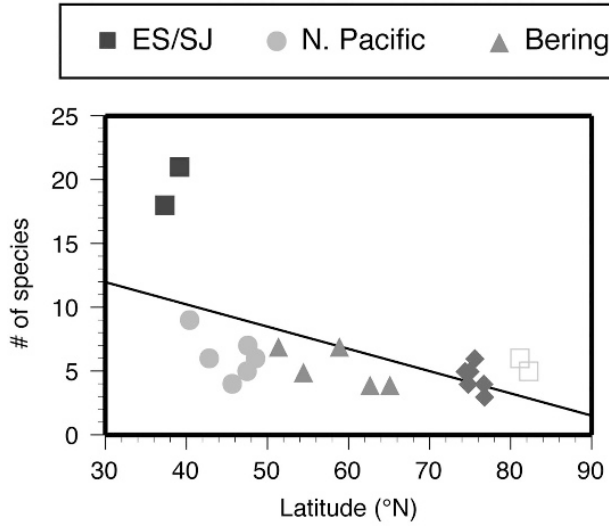

$\checkmark$ Chukchi Sea $\square$ High Arctic
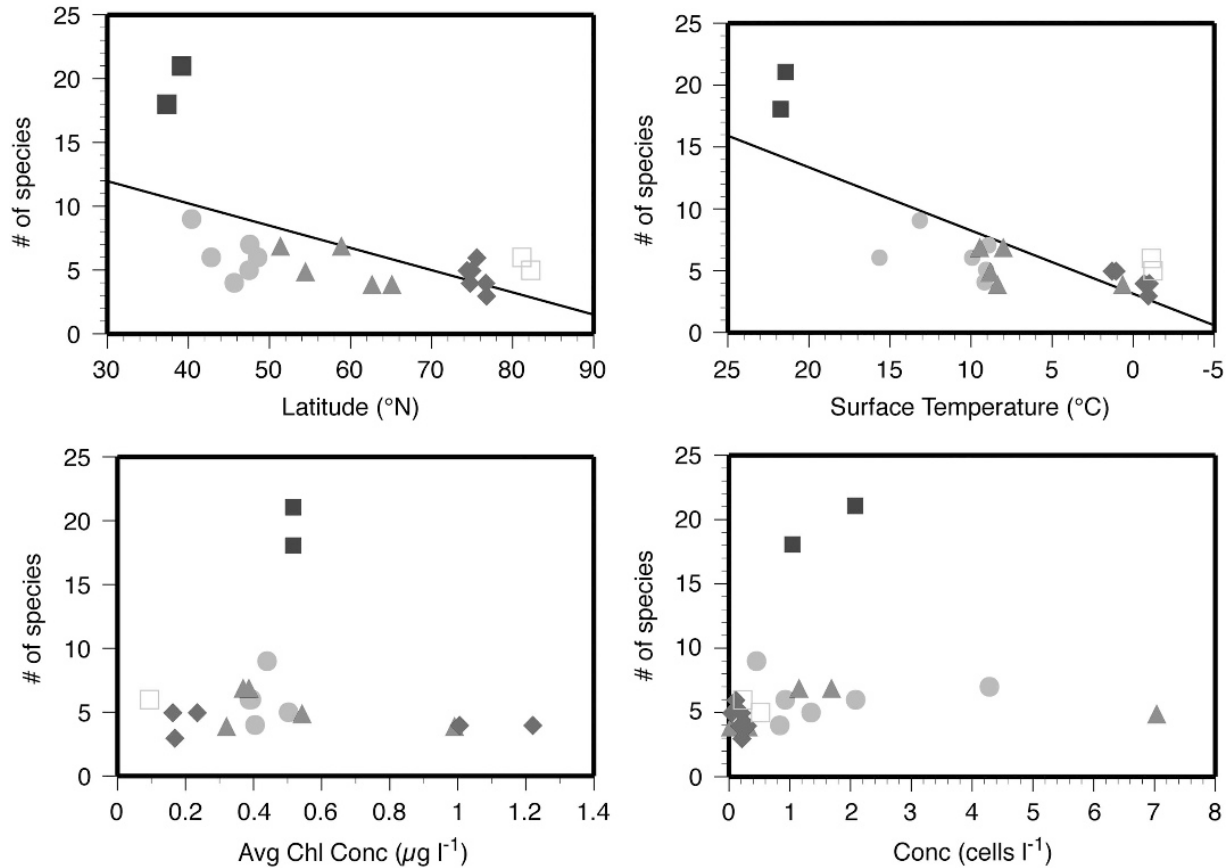

Figure 3 Relationship of species richness of the tintinnid assemblages to: latitude, sea surface temperature (top $10 \mathrm{~m}$ ), average chlorophyll concentration (top $100 \mathrm{~m}$ ), and the abundance of tintinnids. There were significant $(P<0.01)$ negative linear relationships between species richness and latitude $(r=0.6, n=21)$ and sea surface temperature $(r=0.81, n=20)$. ES/SJ indicates East Sea/Sea of Japan. See supplementary data file for the data.

Table 1 Summary of data by region

\begin{tabular}{|c|c|c|c|c|c|c|}
\hline Region & Cells enumerated & Species & Trace species & Size-classes & Size-classes co-habitated & Redundant spp \\
\hline East Sea/Sea of Japan & 2203 & 25 & 5 & 11 & $7(63 \%)$ & 14 \\
\hline North Pacific & 2566 & 13 & 4 & 8 & $4(50 \%)$ & 5 \\
\hline Bering Sea & 2255 & 13 & 2 & 9 & $3(33 \%)$ & 6 \\
\hline Chukchi Sea & 2038 & 8 & 1 & 7 & $1(14 \%)$ & 1 \\
\hline High Arctic & 2496 & 6 & 0 & 6 & $0(0 \%)$ & 0 \\
\hline
\end{tabular}

Trace species are species found as a single individual. Number of size-classes containing more than one species given as size-classes co-habitated. Number of redundant species is the number of species in excess of the number of size-classes.

'ecological redundants', species occupying a sizeclass along with one or more other species. The sizeclass containing the largest number of species was that of the dominant species, Proplectella expolita, which was accompanied by three other species. The five rare or 'trace' species (those found as a single individual) were redundants with one exception. Thus, only one rare form was distinct from all other species in terms of mouth size.

Compared with the East Sea/Sea of Japan, the North Pacific assemblage was composed of fewer species and these were distributed in fewer sizeclasses (Table 1). Half the size-classes contained redundants as they were occupied by more than one species. The dominant species, the large-mouthed Pytchocylis obtusa, was alone in its size-class. None of the trace species formed a distinct size-class, all appeared to be redundants. The Bering Sea assemblage resembled that of the North Pacific in species richness. The assemblage formed nine sizeclasses with the dominant species, Codonellopsis frigida, sharing a size-class with two redundant species. Two other redundant species shared the size-class of the second most abundant species Parafavella parumdentata. The two trace species were alone in their size-class.

Low species richness characterised both Arctic assemblages (Table 1). In the Chukchi Sea the eight species found were distributed in seven size-classes with only the size-class of the dominant species, Acanthostomella norvegica, containing a redundant species. The single trace species was alone in its size-class. The High Arctic population, dominated by Ptychocylis obtusa, was singular in having neither rare species nor redundant species; all six species found were in distinct size-classes. The latitudinal 
decline in species richness we found from the East Sea/Sea of Japan to the High Arctic represented declines in numbers of redundant and trace species. Notably, although there were many fewer species in the high latitudes, the total overall size range of LODs found in the assemblages, 11-75 $\mu \mathrm{m}$, was invariant across all the assemblages.

The data reported here are from a summer time sampling as is the case for most studies of high latitude plankton. In lower latitude coastal systems seasonal changes in species richness of tintinnid assemblages are well documented and summer is usually a period of low diversity (reviewed in Dolan and Pierce, 2013). Few data exist concerning seasonality in open water systems, especially in arctic and sub-arctic waters owing to the technical difficulty of sampling in periods other than summer. The gradient we found may be more prominent in other seasons, for example, when the ice cover is maximal in the Chukchi Sea and High Arctic.

Also worth noting is that rather than harboring cryptic species, some species of the high latitude assemblages have long been suspected to be polymorphic, having variable loricas, which perhaps have been designated wrongly as distinct species. Among these suspected polymorphs are Parafavella spp (Burkovsky 1973; Davis 1978) of which five are reported here (see Supplementary data file). The phenomenon of cryptic species in tintinnids (that is, Santoferrara et al., 2015) may be less common compared with polymorphism as there are species known to display different lorica morphologies, but of the same LOD, previously described as different species and/or genera (that is, Laval-Peuto, 1983; Kim et al., 2013; Bachy et al., 2012). At present it is not clear which phenomenon is more common. Among tintinnids and foraminfera cryptic species are generally segregated either temporally or spatially (for example, de Vargas et al., 1999; Xu et al., 2012; Santoferrara et al., 2015), whereas in polymorphic species the different morphotypes occur together (for example, Dolan et al., 2013, 2014; Dolan, 2015).

The most likely candidates for crypticism are the widespread species, those found from the East Sea/Sea of Japan to the high Arctic such as Ptychocylis obtusa and Acanthostomella norvegica. These species inhabit waters ranging in temperature from $20^{\circ}$ to $-2^{\circ} \mathrm{C}$. However whether or not, for example, an East Sea/Sea of Japan population of a 'species' is genetically distinct from that in the High Arctic would not change species inventories or distributions for the geographically distinct assemblages. Given that cryptic forms of tintinnids appear to be segregated either temporally, that is, seasonally (Xu et al., 2012) or spatially, that is, distinct water masses (Santoferrara et al., 2015), they are unlikely to represent hidden diversity within an assemblage. Hence, in comparing assemblages from different systems the true problematic phenomenon is polymorphism that may inflate apparent species richness of an assemblage. If the five Parafavella species distinguished here (all found in low numbers: 1-5 cells per assemblage, see Supplementary data file) are revealed to be a single species, the species richness of the assemblages of the East Sea/Sea of Japan, North Pacific and Bering Sea may be slightly lower than the numbers reported here.

Besides species richness, differences between the East Sea/Sea of Japan assemblage and higher latitude populations were also evident in the structures of the assemblages. The patterns of species abundance distributions as well as the abundance distributions of size-classes differed among the assemblages (Table 2 and Figure 4). Species abundance distributions of most of the high latitude populations were best fit by a geometric distribution in contrast to the log-series distribution of the East Sea/Sea of Japan (Table 3). For the High Arctic population no single distribution pattern provided a significantly better fit.

Long-tailed log or log-series distributions, with large numbers of relatively rare species, are commonly observed for most natural assemblages (McGill et al., 2007). Long-tailed distributions are typical of abundance curves of planktonic protists determined using molecular techniques (for example, Brown et al., 2009; Edgcomb et al., 2011; Orsi et al., 2012; Bachy et al., 2013). Notably, the pattern can be partially the result of problems arising from sequencing errors and differential sequencing of different taxa, issues which require attention (for example, de Vargas et al., 2015).

The species abundance distribution of the East Sea/Sea of Japan assemblage was best fit by a log model (Table 3). Log distributions, either log-normal or log-series are associated with a multitude of factors governing relative species abundance in the case of the log-normal, or immigration and extinction from a metapopulation in the case of log-series

Table 2 Identity of the dominant species in the assemblages

\begin{tabular}{lcccc}
\hline Region & Dominant species & \% total cells & No. other species in their size-class & Apparent range \\
\hline East Sea/Sea of Japan & Proplectella expolita & 65 & 3 & East Sea/Sea of Japan only \\
North Pacific & Ptychocylis obtusa & 45 & 0 & All \\
Bering Sea & Codonellopsis frigida & 45 & 2 & All but High Arctic \\
Chukchi Sea & Acanthostomella norvegica & 52 & 1 & All \\
High Arctic & Ptychocylis obtusa & 86 & 0 & All \\
\hline
\end{tabular}

Note that dominants accounted for a large portion of the population in all 5 systems and most had a wide apparent range. 
(that is, Hubbell, 2001). Substituting size-classes for species, similar differences were evident as the lognormal distribution of the East Sea/Sea of Japan population contrasted with the mostly geometric distributions of the high latitude assemblages (Table 3). A geometric distribution represents the result of a priority exploitation of resources by individual species in a community and is classically associated with 'immature' or pioneer communities limited by a single resource such as space (for example, Whittaker, 1972). This distribution is also thought to characterize assemblages of low species richness or severe environments (Wilson, 1991). In Antarctic waters, a geometric species abundance distribution was found to describe the species abundance distribution of the entire planktonic ciliate community (Wickham et al., 2011). In tintinnid assemblages, the geometric distribution of LOD size-class abundance is most simply attributable to availability of prey concentration and size given the close relationship between LOD size and prey exploited by tintinnids (Dolan, 2010).

The species found in trace concentrations, just 1 individual in 100 liters, can be considered 'rare'. The phenomenon of rare species has received a good deal of attention (for example, Gaston, 1994). Rare species have become a focus in biodiversity conservation (for example, Lyons et al., 2005). In microbial ecology, the results from high-throughput sequencing commonly suggest the existence of very large numbers of apparently rare species, present in low concentrations (for example, Dunthorn et al., 2014).
Rare species, although low in abundance, may have important roles if they possess key functional traits different from abundant species (Mouillot et al., 2013). In the protistan 'rare biosphere', rare species may be of importance because they can become abundant if conditions change favoring different species with certain characteristics (Caron and Countway, 2009). Admittedly, rare species can also be of minor ecological importance, as in members of the 'accidental rare biosphere' (Weisse, 2014). Regardless of the nature of the rare tintinnid species we found, their numbers decreased markedly with latitude (Figure 5).

Table 3 Results of modeling abundance distribution patterns

\begin{tabular}{lccc}
\hline Region & Log-normal & Geometric & Log-series \\
\hline \multicolumn{2}{l}{ Species abundance distribution fits } & & \\
East Sea/Sea of Japan & $\mathbf{3 . 2}$ & 5.8 & $\mathbf{2 . 7}$ \\
North Pacific & 3.8 & $\mathbf{1 . 9}$ & 3.9 \\
Bering Sea & 3.3 & $\mathbf{0 . 0}$ & 3.4 \\
Chukchi Sea & 4.0 & $\mathbf{2 . 6}$ & 4.3 \\
High Arctic & $\mathbf{5 . 5}$ & $\mathbf{4 . 8}$ & $\mathbf{5 . 7}$ \\
& & & \\
Size-class abundance distribution fits & & \\
East Sea/Sea of Japan & $\mathbf{1 . 8}$ & 4.9 & 2.4 \\
North Pacific & $\mathbf{4 . 4}$ & $\mathbf{3 . 7}$ & 4.7 \\
Bering Sea & 4.4 & $\mathbf{1 . 9}$ & 4.7 \\
Chukchi Sea & 4.6 & $\mathbf{3 . 8}$ & 4.9 \\
High Arctic & $\mathbf{5 . 5}$ & $\mathbf{4 . 8}$ & $\mathbf{5 . 7}$ \\
\hline
\end{tabular}

Lowest AIC values (in bold) indicate the best model fit. Multiple values in bold indicate indistinguishable fits (differences $<1$ ).
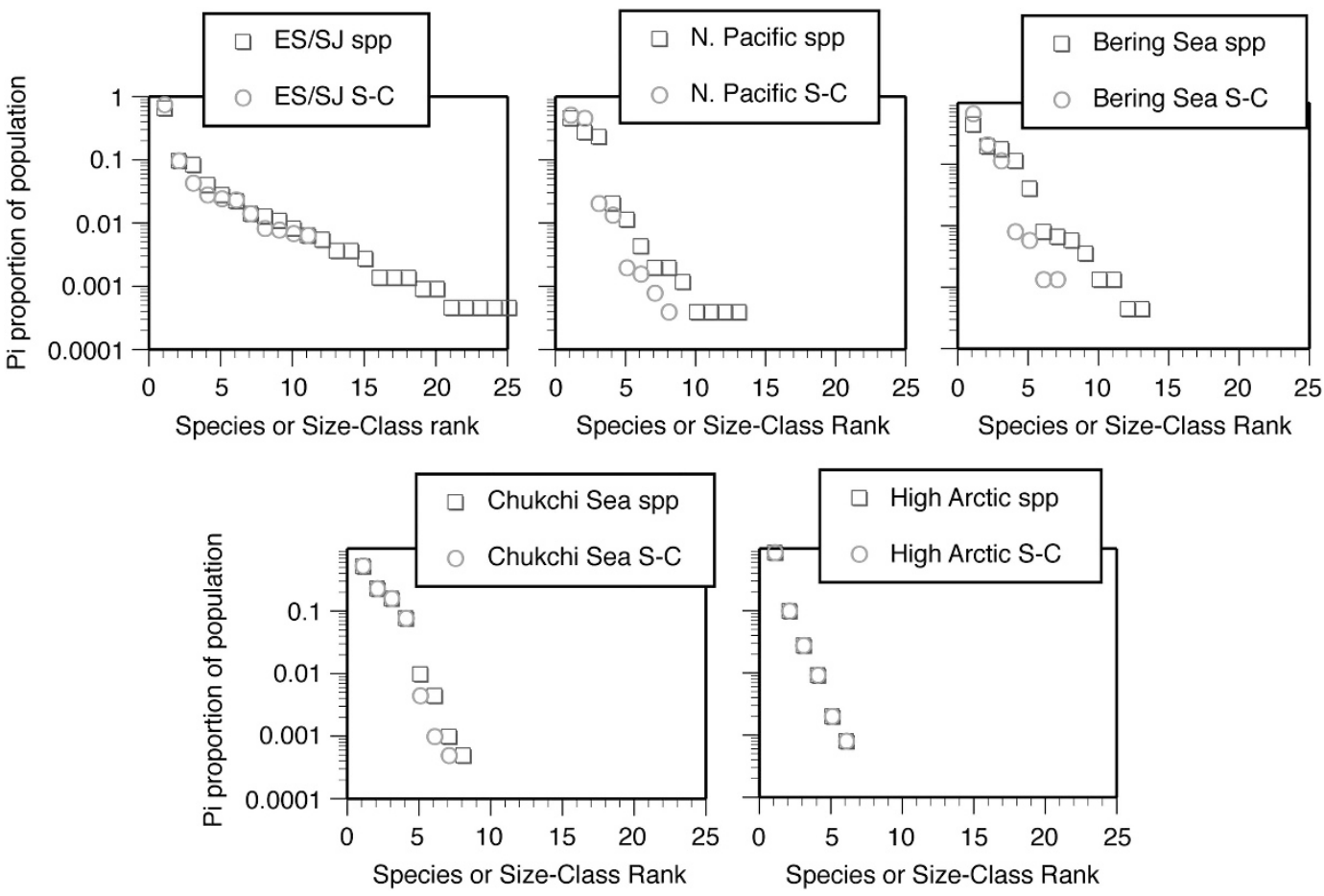

Figure 4 Observed abundance distributions of tintinnid assemblages: species abundance distributions (spp) and size-class abundance (SC) for pooled populations of each of the five systems sampled. ES/SJ indicates East Sea/Sea of Japan. See Table 3 for the results of modeling the abundance distribution shown. 


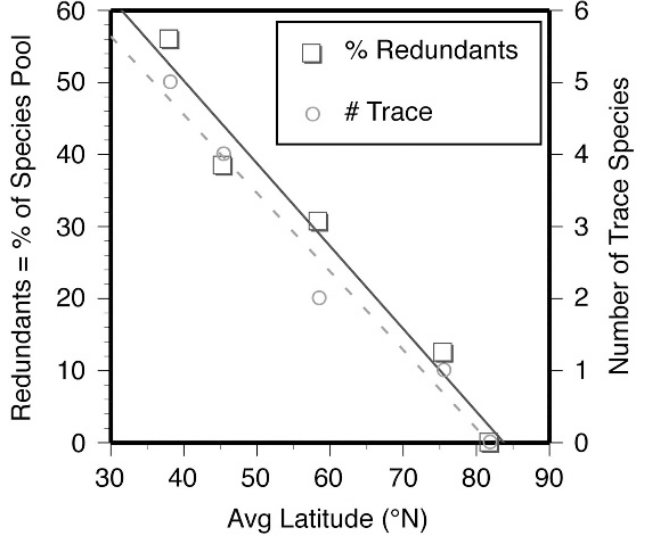

Figure 5 The relationships between the average latitude sampled for each of the five assemblages and the portion of redundant species found (squares) and the number trace species encountered (circles). Significant $(P<0.01)$ negative linear relationships with latitude are evident for both the \% of species pool as redundants $(n=5, r=0.984)$ and the number of trace species $(n=5, r=0.987)$.

Using our non-exclusive categories, a species found as a single cell is defined as rare but if it is in the same LOD size-class as another species, it is also a redundant. However, the majority of redundant species were not rare but relatively abundant, as they were found in far greater than trace concentrations. Redundants were most numerous in the size-classes of the dominant species and can likely replace a dominant species, for example, one subjected to a high rate of specific mortality from a parasite or predator (that is, Coats and Bachvaroff, 2012). A species can change roles from a minor to a major role. In temperate and sub-tropical assemblages of tintinnids, a species can be dominant in one population and a redundant in another (Dolan et al., 2013). In the Bering Sea, Codonellopsis frigida was the dominant form whereas in Chukchi Sea was a redundant species. It has been argued that the existence of redundant species should increase the capability of an assemblage to exploit changes in conditions (Naeem, 1998). Like rare species, we found redundant species declined in relative importance with latitude (Figure 5).

\section{Conclusion}

We found the latitudinal decline in species richness of tintinnid ciliates corresponded to fewer rare species, fewer presumed redundant species and fewer size-classes but without a reduction in the total range of size-classes present. Overall, declines were in the numbers of species accompanying the dominant forms. Interestingly, the dominant forms remained more or less the same set of species. The declines were then in presumed redundant species and numbers of rare species. Both categories declined with latitude to apparent zero values in the High Arctic assemblage (Table 1 and Figure 5). The decline in species richness with latitude in the Northern hemisphere represents declines in the variety of forms in an assemblage and species redundancy. Consequently, there appears to be a latitudinal gradient in the capability of assemblages to adapt to environmental changes in least with regard to size-spectra of available prey items or the loss of a particular dominant species. The latitudinal diversity gradient in another group of planktonic protists, foraminifera, appears closely related to temperature over a wide variety of time scales (Yasuhara et al., 2012), suggesting temperature has a preponderant role in determining species richness. If changes in species occur with distributions shifted northward, Arctic assemblages may become slightly more species-rich and increases in species richness would likely increase the numbers of redundant species. Theoretically, as redundancy among species increases ecosystem stability (Naeem, 1998), global climate change may increase the stability of high latitude ecosystems. However, the relatively small species pools of the northern high latitude assemblages suggest a low capacity to adapt to changing conditions.

\section{Conflict of Interest}

The authors declare no conflict of interest.

\section{Acknowledgements}

The comments and suggestions of Dave Montagnes, three reviewers and the editor on previous versions led to significant improvement in the manuscript. Financial support was provided by the CNRS (France). This research was part of the project titled 'Korea-Polar Ocean in Rapid Transition (KOPRI, PM15040)', funded by the MOF, Korea.

\section{References}

Adams J. (2009). The Holy Grail of ecology: latitudinal gradients. In 'Species Richness: Patterns in the Diversity of Life'. Springer: Berlin, Germany, pp 47-95.

Agatha S, Strüder-Kypke MC. (2012). Reconciling cladistic and genetic analyses in choreotrichid ciliates (Protists, Spirotrichea, Oligotrichea). J Eukaryot Microbiol 59: 325-350.

Agatha S, Laval-Peuto M, Simon P. (2013). The tintinnid lorica. In: Dolan JR, Montagnes DJS, Agatha S, Coats DW, Stoecker DK (eds). The Biology and Ecology of Tintinnid Ciliates: Models for Marine Plankton. Wiley-Blackwell: Oxford, UK, pp 17-41.

Bachy C, Gómez F, López-García P, Dolan JR, Moreira D. (2012). Molecular phylogeny of tintinnid ciliates (Tintinnida, Ciliophora). Protist 163: 873-887.

Bachy C, Dolan JR, López-García P, Deschamps P, Moreira D. (2013). Accuracy of protist diversity assessments: morphology compared to cloning and direct pyrosequencing of 18S rRNA genes and ITS regions using the conspicuous tintinnid ciliates as a case study. ISMEJ 7: 244-255. 
Brown MV, Philip GK, Bunge JA, Smith MC, Bissett A, Lauro FM et al. (2009). Microbial community structure in the North Pacific Ocean. ISMEJ 3: 1374-1386.

Burkovskii IV. (1973). Variability of Parafavella denticulata in the White Sea. Zoologicheskii Zh 52: 1277-1285.

Burnham KP, Anderson DR. (2002). Model selection and multi-model inference: a practical informationtheoretic approach. Springer: New York, NY, USA.

Caron DA, Countway PD. (2009). Hypotheses on the role of the protistan rare biosphere in a changing world. Aquat Microb Ecol 57: 227-238.

Claessens M, Wicjkham SA, Post AF, Reuter M. (2010). A paradox of the ciliates? High ciliate diversity in a resource-poor environment. Mar Biol 157: 483-494.

Coats DW, Bachvaroff TR. (2012). Parasites of tintinnids. In: Dolan JR, Montagnes DJS, Agatha S, Stoecker DK (eds). The Biology and Ecology of Tintinnid Ciliates: Models for Marine Plankton. Wiley-Blackwell: Oxford, UK, pp 146-170.

Davis CC. (1978). Variations of the lorica in the genus Parafavella (Protozoa: Tintinnida) in northern Norway waters. Can J Zool 56: 1822-1827.

de Vargas C, Norris R, Zaninetti L, Gibb SW, Pawlowski J. (1999). Molecular evidence of cryptic speciation in planktonic foraminifers and their relation to oceanic provinces. Proc Natl Acad Sci USA 96: 2864-2868.

de Vargas C, Audic S, Henry N, Decelle J, Mahé F, Logares R et al. (2015). Eukaryotic plankton diversity in the sunlit ocean. Science 348: 1261605.

Doherty M, Tamura M, Costas BA, Ritchie ME, McManus GB, Katz LA. (2010). Ciliate diversity and distribution across an environmental and depth gradient in Long Island Sound, USA. Environ Microbiol 12: 886-898.

Dolan JR. (2010). Morphology and ecology in tintinnid ciliates of the marine plankton: correlates of lorica dimensions. Acta Protoz 49: 235-244.

Dolan JR. (2011). The legacy of the last cruise of the Carnegie: a lesson in the value of dusty old taxonomic monographs. J Plank Res 33: 1317-1324.

Dolan JR. (2015). Planktonic protists: little bugs pose big problems for biodiversity assessments. J Plank Res; doi:10.1093/plankt/fbv079.

Dolan JR, Pierce RW. (2013). Diversity and distributions of tintinnids. In: Dolan JR, Montagnes DJS, Agatha S, Stoecker DK (eds). The Biology and Ecology of Tintinnid Ciliates: Models for Marine Plankton. Wiley-Blackwell: Oxford, pp 214-243.

Dolan JR, Stoeck T. (2011). Repeated sampling reveals differential variability in measures of species richness and community composition in planktonic protists. Environ Microbiol Rep 3: 661-666.

Dolan JR, Jacquet S, Torreton J-P. (2006). Comparing taxonomic and morphological biodiversity of tintinnids (planktonic ciliates) of New Caledonia. Limnol Oceanogr 51: 950-958.

Dolan JR, Ritchie MR, Ras J. (2007). The neutral community structure of planktonic herbivores, tintinnid ciliates of the microzooplankton, across the SE Pacific Ocean. Biogeosciences 4: 297-310.

Dolan JR, Ritchie ME, Tunin-Ley A, Pizay M-D. (2009). Dynamics of core and occasional species in the marine plankton: tintinnid ciliates of the N.W. Mediterranean Sea. J Biogeogr 36: 887-895.

Dolan JR, Landry MR, Ritchie ME. (2013). The speciesrich assemblages of tintinnids (marine planktonic protists) are structured by mouth size. ISMEJ 7: 1237-1243.

Dolan JR, Yang EJ, Lee SH, Kim SY. (2013). Tintinnid ciliates of the Amundsen Sea (Antarctica) Plankton Communities. Pol Res 32: 19784.

Dolan JR, Pierce RW, Bachy C. (2014). Cyttarocylis ampulla, a polymorphic ciliate of the marine plankton. Protist 165: 66-80.

Dunthorn M, Stoeck T, Clamp J, Warren A, Mahé F. (2014). Ciliates and the rare biosphere: a review. J Eukaryot Microbiol 61: 404-409.

Edgcomb V, Orsi W, Bunge J, Jeon S, Christen R, Leslin C et al. (2011). Protistan microbial observatory in the Cariaco Basin, Caribbean. 1. Pyrosequencing vs Sanger insights into species richness. ISMEJ 5: 1344-1356.

Gaston KJ, Spicer JI. (2003). Biodiversity: an introduction. 2nd edn. Blackwell Publishing: Oxford, UK.

Gaston KJ. (1994). Rarity. Chapman \& Hall: London, UK.

Hada Y. (1937). The fauna of Akkeshi Bay IV. The pelagic ciliata. J Fac Sci Hokkaido Imperial Univ, Series 6, Zool 5: 147-216.

Hubbell SR. (2001). The unified neutral theory of biodiversity and biogeography. Princeton University Press: Princeton, USA.

Kim SY, Choi JK, Dolan JR, Shin HC, Lee S, Yang EJ. (2013). Morphological and ribosomal DNA-based characterization of six Antarctic ciliate 5 morphopecies from the Amundsen Sea with phylogenetic analyses. J Eukaryot Microbiol 60: 497-513.

Kofoid CA, Campbell AS. (1929). A Conspectus of the Marine and Freshwater Ciliata Belonging to the suborder Tintinnoinea, with Despcriptions of New Species Principally from the Agassiz Expedition to the Eastern Tropical Pacific 1904-1905. Univ Calif Publ Zool 34: 1-403.

Kofoid CA, Campbell AS. (1939). The Ciliata: The Tintinnoinea, 84: Bulletin of the Museum of Comparative Zoology: Harvard, USA, pp 1-473.

Laval-Peuto M. (1983). Sexual reproduction in Favella ehrenbergii (Ciliophora, Tintinnina). Taxonomical implications. Protistologica 29: 503-512.

Laval-Peuto M, Brownlee DC. (1986). Identification and systematics of the Tintinnina (Ciliophora): evaluation and suggestion for improvement. Ann Inst Océanogr Paris 62: 69-84.

Lima-Mendez G, Faust K, Henry N, Decelle J, Colin S, Carcillo F et al. (2015). Determinants of community structure in the global plankton interactome. Science 348: 1262073 .

Lyons KG, Brigham CA, Traut BH, Schwartz MW. (2005). Rare species and ecosystem functioning. Conserv Biol 19: 1019-1024.

McGill BJ, Etienne RS, Gray JS, Alonso D, Anderson MJ, Benecha HK et al. (2007). Species abundance distributions: moving beyond single prediction theories to integration within an ecological framework. Ecol Lett 10: $995-1015$.

Montagnes DJS. (2013). Ecophysiology and behavior of tintinnids. In: Dolan JR, Montagnes DJS, Agatha S, Stoecker DK (eds). The Biology and Ecology of Tintinnid Ciliates: Models for Marine Plankton. Wiley-Blackwell: Oxford, UK, pp 85-121.

Moulllot D, Bellwood DR, Baraloto C, Chave J, Galzin R, Harmelin-Vivien M et al. (2013). Rare species support vulnerable functions in high diversity ecosystems. PLoS Biol 11: e1001569. 
Naeem S. (1998). Species redundancy and ecosystem reliability. Conserv Biol 12: 39-45.

Orsi W, Song YC, Hallam S, Edgcomb V. (2012). Effect of oxygen minimum zone formation on communities of marine protist. ISMEJ 6: 1586-1601.

Rutherford S, D'Hondt S, Prell W. (1999). Environmental controls on the geographic distribution of zooplankton diversity. Nature 400: 749-752.

Raybaud V, Tunin-Ley A, Ritchie ME, Dolan JR. (2009). Similar patterns of community organization characterize distinct groups of different trophic levels in the plankton of the NW Mediterranean Sea. Biogeosciences 6: 431-438.

Santoferrara LF, Tian M, Alder VA, McManus GB. (2015). Discrimination of closely related species in tintinnid ciliates: New insights on crypticity and polymorphism in the Genus Helicostomella. Protist 16: 78-92.

Weisse T. (2014). Ciliates and the rare biospher- community ecology and population dynamics. J Eukaryot Microbiol 61: 419-433.
Whittaker RH. (1972). Evolution and measurement of species diversity. Taxon 21: 213-251.

Wickham SA, Steinmair U, Kamennaya N. (2011). Ciliate distributions and forcing factors in the Amundsen and Bellinghausen Seas (Antarctic). Aquat Microb Ecol 62: 215-230.

Willig MR, Kaufman DM, Stevens RD. (2003). Latitudinal gradients of biodiversity: patterns, process, scale and synthesis. Annu Rev Ecol Syst 34: 273-309.

Wilson JB. (1991). Methods for fitting dominance/ diversity curves. J Veg Sci 2: 35-46.

$\mathrm{Xu}$ D, Sun P, Shin MK, Kim YO. (2012). Species boundaries in tintinnid ciliates: A case study Morphometric variabilty, molecular characterisation, and temporal distribution of Helicostomella species (Cciliophora, Tintinnina). J Eukaryot Microbiol 59: 351-358.

Yasuhara M, Hunt G, Dowsett HJ, Robinson MM, Stoll DK. (2012). Latitudinal species diversity gradient of marine zooplankton for the last three million years. Ecol Lett 15: 1174-1179.

Supplementary Information accompanies this paper on The ISME Journal website (http://www.nature.com/ismej) 